Mineralogical Journal, Vol. 7, No. 5, pp. 431-437, Oct. 1975

\title{
Vaesite from the Uchinotai deposits, Kosaka mine, Japan
}

\author{
Takeo Sato and Yoshiniko Shimazaki \\ Geological Survey of Japan, 8 Kawada-cho, Shinjuku-ku, Tokyo 162
}

\section{ABSTRACT}

The first occurrence of vaesite in Japan is described from the Kurokotype deposits of the Kosaka mine in Northeast Japan. Micromrobe analysis showed its chemical composition to be very close to $\mathrm{NiS}_{2}$, though it contains small amounts of $\mathrm{Fe}, \mathrm{Cu}$, and $\mathrm{Co}$. Sulfur fugacities at the time of deposition of the vaesite bearing ores were calculated to be $10^{-13.8}, 10^{-11.0}$ $10^{-11.7}$, and $10^{-8.7}-10^{-9.9} \mathrm{~atm}$. at $150^{\circ}, 200^{\circ}$, and $250^{\circ} \mathrm{C}$ respectively on the basis of the observed mineral assemblage.

Vaesite, $\mathrm{NiS}_{2}$, was first described by Kerr (1945) from the Kasompi mine, Katanga, the Republic of Zaire. Though it has been reported from several other localities (e. g., Derriks and Vaes, 1955; Park, 1967; Ramdohr, 1969), detailed description of the mineral is very few. A new occurrence of the mineral from the Kuroko-type deposits of the Kosaka mine, Northeast Japan is here described.

\section{Occurrence}

The Uchinotai deposits are typical Kuroko-type, polymetallic sulfide-sulfate deposits occurring in Miocene acidic volcanic rocks (Horikoshi, 1969; Horikoshi and Sato, 1970). The deposits are composed of several unit ore bodies, and the ores in individual bodies are generally divided into the bedded galena-sphalerite-barite ore (black ore), the bedded pyrite-chalcopyrite ore (yellow ore) and the stockwork pyrite-chalcopyrite-quartz ore (siliceous ore). The bedded 
ores overlie the stockwork ore and are concordant with the over. lying sediments.

Vaesite has been found in microscopic amount in the black ore from the Uchinotai-nishi and the Otarube ore bodies. The mineral
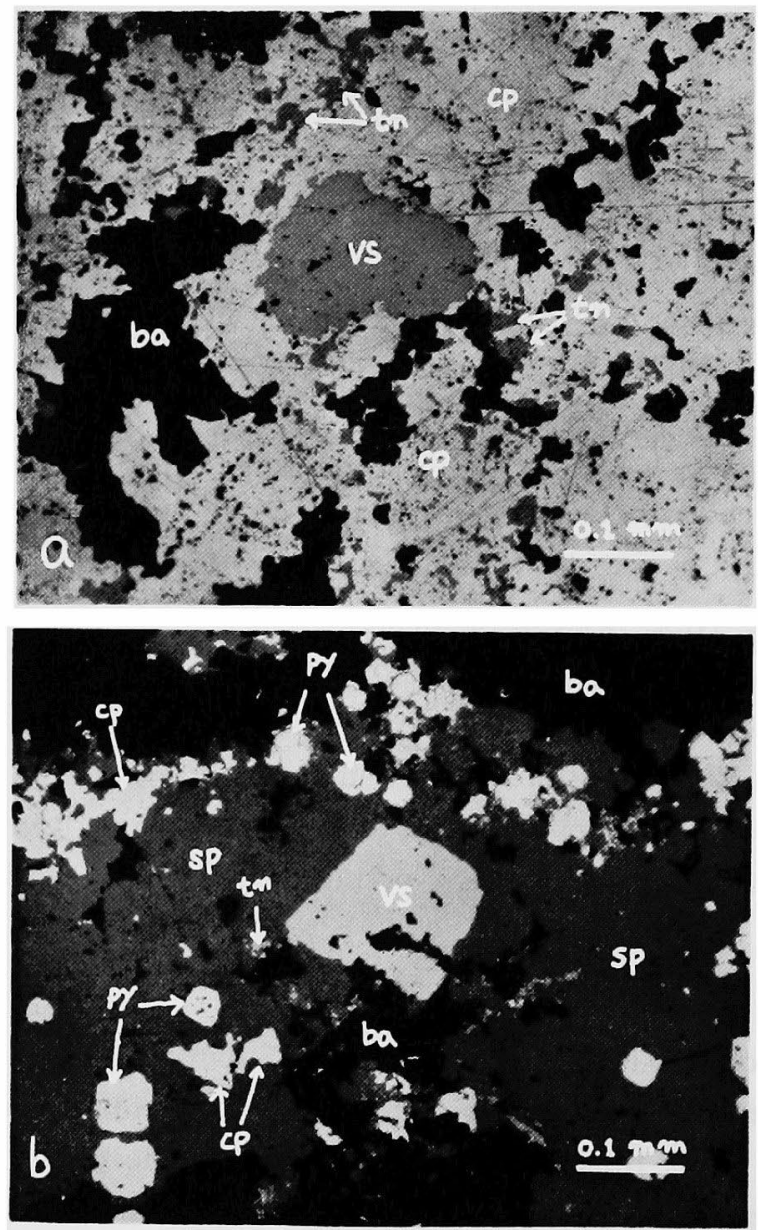

Fig. 1. Photomicrographs of vaesite from the Uchinotai-nishi ore body (a) and the Otarube ore body (b). Reflected light, oil immersion. $v s=$ vaesite, $\mathrm{py}=$ pyrite, $\mathrm{cp}=$ chalcopyrite, $\mathrm{sp}=$ sphalerite, tn $=$ tennantite, ba $=$ barite. 
assemblages of the vaesite-bearing specimens are chalcopyrite-baritegalena-tennantite-vaesite-sphalerite in the Uchinotai-nishi ore body, and barite-sphalerite-galena-pyrite-chalcopyrite-vaesite-electrum in the Otarube ore body. At Uchinotai-nishi ore body, vaesite is in direct contact with chalcopyrite, barite, and tennantite, while in Otarube the direct neighbors are sphalerite, barite, and tennantite. The iron content of the sphalerite associated with vaesite is very low (less than 0.1 mole $\% \mathrm{FeS}$ ) and the electrum has a composition close to $\mathrm{Au}_{6} \mathrm{Ag}_{4}$.

The vaesite occurs as minute anhedral to subhedral grains up to 200 microns in diameter (Fig. 1). Under the ore microscope, it is creamy grey, isotropic and slightly darker than chalcopyrite. No internal reflection is observed. Its polishing hardness is slightly lower than pyrite and distinctly higher than chalcopyrite.

\section{Chemistry}

The chemical compositions of six vaesite grains from the Uchinotai-nishi and the Otarube ore bodies are listed in Table 1. The

Table 1. Composition of vaesite from the Uchinotai-nishi ore body $(1-3)$ and the Otarube ore body $(4-6)$.

\begin{tabular}{lrrrrrr}
\hline & 1 & 2 & 3 & 4 & 5 & 6 \\
\hline $\mathrm{Ni}$ & 44.7 & 44.1 & 44.4 & 45.4 & 43.9 & 44.7 \\
$\mathrm{Fe}$ & 1.2 & 1.3 & 0.9 & 0.9 & 0.8 & 1.7 \\
$\mathrm{Cu}$ & 0.6 & 0.7 & 0.6 & 1.0 & 0.8 & 1.0 \\
$\mathrm{Co}$ & 0.5 & 0.3 & - & 1.6 & 1.4 & - \\
$\mathrm{S}$ & 52.8 & 50.9 & 52.5 & 49.2 & 51.8 & 50.6 \\
\hline Total & 99.8 & 97.3 & 98.4 & 98.1 & 98.8 & 98.0 \\
\hline
\end{tabular}

1. $\left(\mathrm{Ni}_{0.99} \mathrm{Fe}_{0.02} \mathrm{Cu}_{0.01} \mathrm{Co}_{0.01}\right)_{0.97} \mathrm{~S}_{2}$

2. $\left(\mathrm{Ni}_{0.95} \mathrm{Fe}_{0.03} \mathrm{Cu}_{0.01} \mathrm{Co}_{0.006}\right)_{1.00} \mathrm{~S}_{2}$

3. $\left(\mathrm{Ni}_{0.93} \mathrm{Fe}_{0.02} \mathrm{Cu}_{0.01}\right)_{0.86} \mathrm{~S}_{2}$

4. $\left(\mathrm{Ni}_{1.01} \mathrm{Fe}_{0.02} \mathrm{Cu}_{0.02} \mathrm{Co}_{0.03}\right)_{1.08} \mathrm{~S}_{2}$

5. $\left(\mathrm{Ni}_{0.93} \mathrm{Fe}_{0.02} \mathrm{Cu}_{0.02} \mathrm{Co}_{0.03}\right)_{1.00} \mathrm{~S}_{2}$

6. $\left(\mathrm{Ni}_{0.97} \mathrm{Fe}_{0.04} \mathrm{Cu}_{0.02}\right)_{1.02} \mathrm{~S}_{2}$ 
Table 2. X-ray diffraction pattern of vaesite from the Uchinotai-nishi ore body.

\begin{tabular}{|c|c|c|c|c|c|}
\hline \multicolumn{3}{|c|}{$\begin{array}{l}\text { Vaesite from the Uchinotai-nishi } \\
\text { ore body, Kosaka mine } \\
\text { (present study) }\end{array}$} & \multicolumn{3}{|c|}{$\begin{array}{l}\text { Vaesite from Kasompi mine, } \\
\text { Katanga, Belgian Congo } \\
\text { (A.S.T.M. card, 11-99) }\end{array}$} \\
\hline$d(\AA)$ & $I$ & & $h k l$ & $d(\AA)$ & $I$ \\
\hline 3.43 & s & gn & & & \\
\hline 3.26 & $\mathrm{w}$ & vs & 111 & 3.27 & 20 \\
\hline 3.03 & $\mathrm{~s}$ & $\mathrm{cp}$ & & & \\
\hline 2.95 & $\mathrm{~s}$ & $\mathrm{gn}(+\mathrm{tn})$ & & & \\
\hline 2.83 & $\mathrm{~s}$ & vs & 200 & 2.83 & 100 \\
\hline 2.53 & $\mathrm{~m}$ & vs & 210 & 2.54 & 40 \\
\hline 2.33 & $\mathrm{~m}$ & vs & 211 & 2.32 & 40 \\
\hline 2.10 & $\mathbf{s}$ & $\mathrm{gn}$ & & & \\
\hline \multirow[t]{2}{*}{2.00} & $\mathrm{~m}$ & vs & 220 & 2.00 & 50 \\
\hline & & & 221 & 1.892 & 5 \\
\hline 1.856 & $\mathrm{~m}$ & $\mathrm{cp}$ & & & \\
\hline 1.784 & $\mathrm{~m}$ & gn & & & \\
\hline \multirow[t]{2}{*}{1.707} & $\mathrm{~s}$ & vs & 311 & 1.707 & 80 \\
\hline & & & 222 & 1.634 & 20 \\
\hline 1.591 & $\mathrm{w}$ & $\mathrm{cp}$ & & & \\
\hline 1.568 & $\mathrm{w}$ & vs & 320 & 1.570 & 30 \\
\hline \multirow[t]{3}{*}{1.514} & vw & vs & 321 & 1.514 & 30 \\
\hline & & & $\begin{array}{l}410 \\
322\end{array}$ & 1.375 & 10 \\
\hline & & & 411 & 1.336 & 5 \\
\hline \multirow[t]{4}{*}{1.322} & $\mathrm{w}$ & $g n$ & & & \\
\hline & & & 331 & 1.304 & 20 \\
\hline & & & 320 & 1.268 & 20 \\
\hline & & & 421 & 1.234 & 20 \\
\hline \multirow[t]{4}{*}{1.208} & $w$ & $\mathrm{vs}(+\mathrm{gn}, \mathrm{cp})$ & 332 & 1.208 & 10 \\
\hline & & & 422 & 1.158 & 30 \\
\hline & & & 430 & 1.133 & 5 \\
\hline & & & 431 & 1.113 & 5 \\
\hline \multirow[t]{3}{*}{1.092} & $\mathrm{w}$ & vs & $\begin{array}{l}511 \\
333\end{array}$ & 1.091 & 60 \\
\hline & & & $\begin{array}{l}520 \\
432\end{array}$ & 1.053 & 20 \\
\hline & & & 521 & 1.035 & 20 \\
\hline 1.004 & $\mathrm{w}$ & vs & 440 & 1.003 & 40 \\
\hline
\end{tabular}

$v s=$ vaesite,$g n=$ galena,$c p=$ chalcopyrite, $t n=$ tennantite. 
analyses were done by JXA-3 electron microprobe using metals for $\mathrm{Ni}$ and $\mathrm{Co}$, and a chemically analysed chalcopyrite for $\mathrm{Cu}, \mathrm{Fe}$ and $\mathrm{S}$, as standards. The measured values were corrected for atomic number effect by Bishop-Springer's method and for absorption by Philbert's method using Heinrich's absorption coefficients.

The mineral contains small amounts of $\mathrm{Fe}, \mathrm{Cu}$, and $\mathrm{Co}$, replacing $\mathrm{Ni}$ but is very close to a pure $\mathrm{NiS}_{2}$. Se was not detected.

\section{$X$-ray diffraction data}

The material from Uchinotai was removed from the polished surface under the microscope and studied by X-ray powder diffraction. The data obtained are shown in Table 2. Although considerable amounts of galena and chalcopyrite are present, the lines other than those of these two minerals agree well with the data for vaesite from the type locality.

Sulfur fugacities at the time of ore deposition

Estimation of sulfur fugacities at the time of ore deposition can be made on the basis of the observed mineral assemblage, if the associated minerals are assumed to have formed under equilibrium conditions.

Let us consider the following two sulfidation reactions;

$$
\begin{aligned}
& \begin{aligned}
5 \mathrm{CuFeS}_{2}+\mathrm{S}_{2} \rightleftarrows & \mathrm{Cu}_{5} \mathrm{FeS}_{4}+4 \mathrm{FeS}_{2} \\
\text { (chalcopyrite) } & \text { (bornite) (pyrite) }
\end{aligned} \\
& \mathrm{Ni}_{3} \mathrm{~S}_{4}+\mathrm{S}_{2} \rightleftarrows 3 \mathrm{NiS}_{2} \\
& \text { (polydymite) } \quad \text { (vaesite) }
\end{aligned}
$$

The $\log f_{\mathrm{S}_{2}}$ values for the reaction (1) can be calculated from the $\Delta G$ values determined as a function of temperature (Barton and Toulmin, 1964). The $\log f_{\mathrm{S}_{2}}-T$ relation for the reaction (2) is also available (Barton and Skinner, 1967). From several lines of evidences, 
the formation temperatures of the black ores in the Kuroko-type deposits are believed to be in the range of $150^{\circ}$ to $250^{\circ} \mathrm{C}$ (Tokunaga et al., 1970 ; Kajiwara, 1970, 1971 ; Sato, 1971). Thus, the ranges of sulfur fugacities possible for ores containing chalcopyrite and vaesite but lacking in bornite and polydymite, are estimated as $\approx 10^{-13.8}, 10^{-11.0}-10^{-11.7}$ and $10^{-8.7}-10^{-9.9}$ atm. at $150^{\circ}, 200^{\circ}$ and $250^{\circ} \mathrm{C}$, respectively. On the basis of the experimental work by Barton and Toulmin (1966), the very low iron content in the coexisting sphalerite appears to be consistent with the sulfur fugacities estimated above.

\section{Concluding remarks}

Most of the vaesites reported to date are inferred to have been formed from other Ni-bearing sulfides or arsenides through alteration or weathering processes (e. g., Ramdohr, 1969; Uytenbogaardt and Burke, 1971). The vaesite described here, however, is apparently of primary origin judging from its mode of occurrence.

Nickel content of the ores from Kuroko-type deposits is generally very low ; the average for the Uchinotai-nishi ore body is 10$20 \mathrm{ppm}$. It seems likely that nickel was concentrated in the hydrothermal solution of the later stages and was precipitated as vaesite under relatively high sulfur fugacities.

Acknowledgements-The authors wish to thank Dr. Akira Sasaki of the Geological Survey of Japan and Dr. Hidehiko Shimazaki of the University of Tokyo for critical reading of the manuscript.

\section{REFERENCES}

BARTON, P.B., Jr. \& SkINNER, B.J. (1967) Geochemistry of hydrothermal ore deposits, H.L. Barnes, ed., 236. Holt, Rinehart and Winston, New York.

Barton, P.B., Jr. \& Toulmin, P., III (1964) Econ. Geol., 59, 747. Barton, P.B., Jr. \& Toulmin, P., III (1966) Econ. Geol., 61, 815. Derriks, J. J. \& VAes, J.F. (1955) Proc. U.N. Intern. Conf. Peaceful Uses At. Energy, 1st, Geneva, 1955, 6, 94. 
HoRIKoshi, E. (1969) Miner. Deposita, 4, 321.

HoRIKoshi, E. \& SATo, T. (1970) Volcanism and ore genesis, T. TATsUMI, ed,, 181. Univ. Tokyo Press, Tokyo.

KajIWARA, Y. (1970) Volcanism and ore genesis, T. TATsumi, ed., 367. Univ. Tokyo Press, Tokyo.

KAJIWARA, Y. (1971) Geochem. Journ., 4, 157.

KERR, P.F. (1945) Amer. Miner., 30, 483.

PARK, W.C. (1967) Miner. Deposita, 2, 372.

RAMDOHR, P. (1969) The ore minerals and their intergrowths. Pergamon, Oxford.

Sato, T. (1971) Soc. Mining Geol. Japan Spec. Issue, 2, 137.

Tokunaga, M., Miyazawa, T., Honma, H. \& Park, H. (1970) Collected Abstracts of IMA-IAGOD Meetings '70, Tokyo-Kyoto, 246.

UytenbogaARdT, W. \& Burke, E. A. J. (1971) Tables for microscopic identi. fication of ore minerals. Elsevier, Amsterdam-London-New York.

Received June 24, 1974. 